\title{
NORMATIVA LEGAL, RECAUDOS ÉTICOS Y PRÁCTICA ARQUEOLÓGICA. UN ESTUDIO COMPARATIVO DE ARGENTINA Y CHILE
}

\author{
LEGAL REGULATION, ETHICAL ISSUES AND ARCHAEOLOGICAL PRACTICE. \\ A COMPARATIVE STUDY OF ARGENTINA AND CHILE
}

\author{
María Luz Endere ${ }^{1}$ y Patricia Ayala ${ }^{2}$
}

\begin{abstract}
Las cuestiones relativas al patrimonio cultural indígena, y en especial el tratamiento ético de los restos humanos, han motivado importantes cambios que tendrán un impacto creciente en las prácticas de campo y de laboratorio. Sin embargo, esto no parece generar mayores preocupaciones en los arqueólogos, siendo la actitud general de indiferencia y desinterés en debatir estos temas y evaluar sus implicancias en el desempeño profesional. El objetivo de este trabajo es discutir esta temática comparando la situación en Argentina y Chile, teniendo en cuenta el amplio reconocimiento a los derechos de los pueblos indígenas que se ha hecho en los últimos años y los códigos de ética profesionales utilizados a nivel nacional e internacional, con el fin de plantear lineamientos generales sobre los recaudos éticos que podrían contemplarse en el desarrollo de la práctica arqueológica.
\end{abstract}

Palabras claves: derechos indígenas, arqueología, práctica profesional, código de ética.

Cultural heritage issues, especially those concerning the ethical treatment of human remains have promoted important changes which will have an increasing impact on archaeological fieldwork and laboratory practices. However, these issues seem not to be a major cause for concern among most archaeologists, who seem to show little interest in debating the consequences of these changes to their profession. This paper discusses this issue through a comparison of the situation found in Argentina and Chile that takes into account both the widespread recognition of indigenous peoples' rights and the development of codes of professional ethics at national and international levels over the last few years in order to provide recommendations concerning ethical considerations that practicing archaeologists should adopt.

Key words: Indigenous rights, professional practice, archaeology, codes of ethics.

\section{El Reconocimiento de los Derechos de los Pueblos Indígenas en el Ámbito Internacional}

En la segunda mitad del siglo XX, cuando ya se había consolidado en el mundo el proceso de descolonización y se hallaba vigente la Declaración Universal de los Derechos del Hombre de las Naciones Unidas (ONU), se inició un proceso de reconocimiento de los derechos de los pueblos indígenas cuyo primer hito fue la adopción, por parte de la Organización Internacional del Trabajo (OIT), del Convenio 107 sobre Poblaciones Indígenas y Tribales en 1957. No obstante, esta lucha no se detuvo y unas décadas después fue propuesto uno nuevo con el objetivo de enfatizar el aporte de los pueblos indígenas a la diversidad cultural de la humanidad. En este convenio, que lleva el $\mathrm{N}^{\circ} 169$, se efectuó un amplio reconocimiento de sus derechos.
Sin embargo, aún quedaba un largo camino por recorrer para que los derechos de los pueblos indígenas adquirieran el estatus de derechos humanos. Algunos hitos importantes en ese sentido fueron la Declaración sobre los Derechos de las Personas pertenecientes a Minorías Nacionales o Étnicas, Religiosas y Lingüísticas aprobada en 1992. A lo que se suma la decisión de la Asamblea General de la ONU de declarar el período 1995-2004 como la Década Internacional de los Pueblos Indígenas del Mundo con el objeto de contribuir a la mejora de las condiciones de vida de estos pueblos. Como corolario de este proceso y después de más de diez años de haberse adoptado un primer anteproyecto de declaración por parte de la Subcomisión de Prevención de la Discriminación y Protección de Minorías, la Asamblea General de Naciones Unidas aprobó en 2007 la Declaración sobre los derechos

1 CONICET-PATRIMONIA-INCUAPA, Facultad de Ciencias Sociales, Universidad Nacional del Centro de la Provincia de Buenos Aires. Avda. del Valle 5737-Olavarría, Argentina. mendere@ soc.unicen.edu.ar

2 Instituto de Investigaciones Arqueológicas y Museo R. P. Gustavo Le Paige s. j., Universidad Católica del Norte. Calle Gustavo Le Paige 380, San Pedro de Atacama, Chile. payala_rocabado@ hotmail.com 
de los pueblos indígenas, otorgándole finalmente a estos el estatus de derechos humanos.

\section{Patrimonio Cultural y Reclamos Indígenas}

Los reclamos de agrupaciones indígenas sobre el patrimonio cultural, especialmente por los restos humanos de sus antepasados, tuvieron su origen en Estados Unidos en los años setenta ${ }^{1}$, en el marco de un fuerte movimiento por los derechos indígenas en ese país (Deloria 1970, 1995; Echo-Hawk y Echo-Hawk 1994), paralelamente a lo cual los aborígenes australianos comenzaron a oponerse a la excavación de tumbas en sus territorios (Hubert 1992:107-108). Estos reclamos generaron reacciones en el ámbito académico, especialmente entre quienes se negaban a aceptarlos en nombre de la "ciencia" (Morell 1995; también Deloria 1992, 1999:72-73), aunque surgieron voces a favor de la necesidad de abrir el debate y reflexionar acerca de estas cuestiones en el seno de la comunidad científica (Webb 1987; Zimmerman 1987). Fruto de las discusiones entre investigadores y representantes indígenas iniciadas durante el primer Congreso organizado por el World Archaeological Congress (WAC) en Southampton, Reino Unido en 1986, se adoptó el Acuerdo de Vermillion (WAC 1990) que marcó un hito en la materia. Este acuerdo contiene los siguientes puntos:

1. Respeto por todos los restos humanos, cualquiera sea su origen, raza, religión, nacionalidad, costumbre y tradición.

2. Respeto por los deseos del muerto en lo referente a la disposición de su cuerpo, si ello es conocido o puede ser inferido, en la medida que sea posible, razonable y legal.

3. Respeto por los deseos de las comunidades locales y de los parientes o guardianes del muerto, en la medida que sea posible, razonable y legal.

4. Respeto por el valor de la investigación científica de partes esqueletarias, momificadas y otros restos humanos (incluyendo homínidos fósiles) cuando se prueba que tal valor existe.

5. El acuerdo sobre la disposición de restos fósiles, esqueletarios, momificados y otros restos debe ser alcanzado mediante una negociación sobre la base del respeto mutuo por el interés legítimo de las comunidades por la adecuada disposición de sus ancestros, así como el interés legítimo de la ciencia y de la educación.
6. El expreso reconocimiento de que el interés de los diversos grupos étnicos así como el de la ciencia son legítimos y deben ser respetados permitirá alcanzar y poner en práctica acuerdos aceptables (en el futuro).

El activismo indígena impulsó la sanción de novedosas normas legales relativas a la repatriación de restos humanos y objetos sagrados en algunos países anglosajones, especialmente en Estados Unidos donde se aprobó en 1990 la ley federal conocida como NAGPRA (Native American Graves Protection and Repatriation $A c t)^{2}$. Esta norma tiene por objeto proteger las tumbas indígenas en tierras federales y tribales, otorgándole a los nativos americanos el control sobre el tratamiento de las tumbas aún no identificadas, al tiempo que prohíbe la comercialización de esqueletos indígenas. Asimismo exige el inventario y la repatriación de los restos humanos que se encuentren en manos de instituciones que reciban fondos federales, así como la devolución de los objetos funerarios o sagrados robados o impropiamente adquiridos y otras propiedades comunales significativas que sean reclamadas por sus dueños tradicionales. Esta ley admite la repatriación si se prueba la existencia de un descendiente en línea directa o demostrando que el bien era propiedad o estaba controlado por la tribu o por alguno de sus miembros. Uno de sus aspectos más novedosos es la flexibilidad de la prueba de la filiación cultural que puede basarse en "información geográfica, de parentesco, biológica, arqueológica, antropológica, lingüística, folclórica, tradición oral, histórica, así como toda otra información relevante u opinión experta" (Sec.7 a-4). Se admiten dos excepciones a la repatriación. La primera consiste en la acreditación, por parte de los museos, de su derecho de posesión sobre los objetos reclamados (e.g. adquiridos por cesión voluntaria). La segunda, se refiere a los ítems culturales que están siendo objeto de estudios científicos, debiendo hacerse efectiva su devolución dentro de los noventa días de haberse completado dichos estudios (Sec. 7 b).

Las consecuencias de la aplicación de esta ley dieron lugar a encendidos debates en el ámbito académico, en donde se evidenció la preocupación de algunos investigadores que la consideraban un serio riesgo a la continuidad de sus estudios (Anyon y Thornton 2002; Bray 1996; Hurst 2000; Swidler et al. 1997).

Los reclamos indígenas han motivado además cambios en las políticas de algunos museos que 
decidieron, en algunos casos, retirar los restos humanos de sus exhibiciones y proveer información sobre sus colecciones (e.g. Museo de Pitt Rivers, Oxford) y, en otros, accedieron voluntariamente a su devolución (e.g. Universidad de Cambridge en 1990; el National Museum of Natural History -NMNHdel Smithsonian que accedió a la repatriación de Larsen Bay en 1991) (Endere 2000b).

Algunos códigos de ética profesionales comenzaron a considerar los restos humanos y objetos sagrados asociados como "materiales sensibles" que demandan una especial consideración (e.g. Código de ICOM de 1986). Otras asociaciones han contemplado en sus códigos de ética el reconocimiento del legítimo interés de las comunidades indígenas respecto de los restos humanos de sus ancestros (e.g. Society of Professional Archaeologists Guidelines, 1987; American Association of Museums, Australian Archaeological Association Code, en 1991). Es particularmente interesante destacar que el Código de Deontología del ICOM para Museos ${ }^{3}$, en su versión revisada de 2004, contempla las siguientes recomendaciones:

\subsection{Materiales culturales delicados}

Las colecciones de restos humanos u objetos con carácter sagrado sólo se deben adquirir si se pueden conservar con seguridad y ser tratadas con respeto. Esto debe hacerse de conformidad con las normas profesionales y los intereses y creencias de las comunidades o grupos étnicos o religiosos de donde provienen, si es que se conocen.

3.7 Restos humanos y objetos con carácter sagrado

Las investigaciones sobre restos humanos y objetos con carácter sagrado se deben efectuar de conformidad a las normas profesionales, respetando los intereses y creencias de las comunidades y grupos étnicos o religiosos de los que proceden los objetos.

4.3 Exposición de objetos delicados Los restos humanos y los objetos de carácter sagrado deben presentarse de conformidad con las normas profesionales y teniendo en cuenta, si se conocen, los intereses y creencias de las comunidades y grupos étnicos o religiosos de los que proceden. Deben presentarse con sumo tacto y respetando los sentimientos de dignidad humana de todos los pueblos.

\section{Derechos Humanos Versus Derecho a la Investigación Científica}

Se ha discutido ampliamente el valor jurídico de una declaración de derechos humanos de la ONU en tanto norma de derecho positivo internacional. En primer lugar, es necesario aclarar que una declaración no posee el estatus jurídico de una convención internacional que, al ser ratificada por ley del Estado pasa a formar parte de su derecho interno y, a su vez al depositarse el instrumento de ratificación en el organismo internacional correspondiente, el país se obliga a cumplirla a nivel internacional al constituirse en Estado parte de la Convención. Por el contrario, las declaraciones aprobadas mediante una resolución de la Asamblea General de la ONU sólo pueden tener el carácter de recomendaciones y no constituyen normas de carácter vinculante. No obstante, la opinión dominante en la doctrina afirma el carácter obligatorio de las Declaraciones de Derechos Humanos en forma indirecta, basándose en que los derechos reconocidos en ellas representan "principios generales del derecho de las naciones civilizadas". Cabe destacar que estos principios constituyen una de las cinco fuentes de derecho internacional reconocidas por el Estatuto de la Corte Internacional de Justicia (art. 38.1) para ser aplicadas por ese tribunal. Por otra parte, las resoluciones de la Asamblea General de la ONU, además de su valor jurídico, tienen importancia moral y política que los Estados no pueden desconocer. Todas estas consideraciones sirven de base para evaluar el impacto de algunas disposiciones contenidas en la Declaración de 2007 relativas a sitios y colecciones arqueológicas, transcritas a continuación:

Los pueblos indígenas tienen derecho a practicar y revitalizar sus tradiciones culturales y costumbres. Esto incluye el derecho de mantener, proteger y desarrollar las manifestaciones de su cultura pasadas, presentes y futuras, tales como sitios arqueológicos e históricos, artefactos, diseños, ceremonias, tecnologías, artes visuales y dramáticas y literatura.

Los Estados garantizarán este derecho a través de mecanismos efectivos, los cuales pueden incluir la restitución, desarrollada conjuntamente con los pueblos indígenas, con respecto a su propiedad cultural, 
intelectual, religiosa y espiritual tomada sin su consentimiento libre, previo e informado $\mathrm{o}$ en violación a sus leyes, tradiciones y costumbres (art. 11).

Los pueblos indígenas tienen derecho a manifestar, practicar, desarrollar y enseñar sus tradiciones espirituales y religiosas, costumbres y ceremonias; el derecho a mantener, proteger y tener acceso privado a sus sitios religiosos y culturales; el derecho a usar y controlar sus objetos ceremoniales y el derecho a la repatriación de sus restos humanos.

Los Estados deberán garantizar el acceso a y/o la repatriación de objetos ceremoniales $\mathrm{y}$ restos humanos que se encuentren en su poder a través de mecanismos justos, transparentes y efectivos desarrollados en conjunto con los pueblos indígenas involucrados (art. 12).

Los pueblos indígenas tienen derecho a mantener, controlar, proteger y desarrollar su patrimonio cultural, conocimiento tradicional y expresiones culturales tradicionales (...). También tienen derecho a mantener, controlar, proteger y desarrollar su propiedad intelectual sobre su patrimonio cultural, conocimiento tradicional y expresiones culturales tradicionales. Los Estados deben tomar medidas efectivas para reconocer y proteger el ejercicio de esos derechos (art. 31).

\section{La Situación Jurídica de los Pueblos Indígenas en Argentina}

La primera Carta Magna de Argentina fue aprobada en 1853. Para entonces, los pueblos indígenas que habitaban en el noroeste y el centro del país ya habían sido sometidos, fruto del proceso colonial. Sin embargo, aquellos ubicados en Pampa y Patagonia, tanto como en las áreas selváticas del Gran Chaco se hallaban en libertad y ocupaban territorios no controlados por el gobierno nacional y que eran considerados estratégicos para consolidar su territorio y acceder a los recursos naturales que aquellos explotaban. Es por ello que la Constitución de 1853 se ocupaba de este segundo grupo, autorizando al Congreso "a asegurar la seguridad de las fronteras", "mantener relaciones pacíficas con los indios" y "promover su conversión al catolicismo" (art. 67 inc. 15). Consecuentemente con ese objetivo en 1879 el gobierno emprendió una guerra contra los indígenas de Pampa y Patagonia, conocida como "la Conquista del Desierto". Luego de concluida, su estatus jurídico cambió sustancialmente, ellos dejaron de ser pueblos "bárbaros" que debían ser sometidos (art. 1 Ley 752/1875) para ser considerados como "incapaces de derecho" y objeto de asistencia permanente por parte del Estado (e.g. Decreto de 1899 de Defensa Legal de los Aborígenes; Leyes 1311/1883 y 1744/1885). Su confinamiento en reservas y reducciones tenía el propósito de escolarizarlos e inculcarles hábitos de trabajo productivo. Esta política de "colonización y domesticación" (Carrasco 2002) se mantuvo invariable por décadas. Durante los tres gobiernos radicales (1916 y 1930) se reconocía desde el discurso oficial la necesidad de efectuar una reparación histórica y cultural con los pueblos indígenas garantizándoles el acceso igualitario a las garantías constitucionales. Sin embargo, seguía imperando la política de tutela sobre estas comunidades por lo que su único resultado fue la creación de una Comisión Honoraria de Reducciones de Indios. Hacia 1946 se produjo un cambio hacia la “integración sociocultural” de los indígenas al ser incorporados al padrón electoral y otorgarles los documentos para votar en las elecciones que llevó al gobierno a Juan D. Perón (1946-1955) (Carrasco 2000, 2002). Se creó la Dirección de Protección del Aborigen y el Instituto Étnico Nacional, se modificaron las cláusulas relativas a "los indios" en la reforma constitucional de 1949 y se ratificó el Convenio 50 de la OIT. Sin embargo, estas políticas de integración se vieron truncadas con el golpe de Estado de 1955 (Slavsky 1992, 1997). En la década de los sesenta se comenzó a desarrollar una política de corte indigenista. La ratificación del Convenio 107 de la OIT mediante la Ley 14.932/59 y la creación de un Consejo de Asuntos Indígenas en 1961, sumado al primer censo indígena de 1966 fueron sus principales hitos. Los cambios más significativos, sin embargo, se producirían luego del retorno de la democracia en la década de 1980. En efecto, la Ley 23.302/85 sobre "política indígena y apoyo a las comunidades indígenas" reconoce el estatus legal de las comunidades indígenas ${ }^{4} \mathrm{y}$ declara:

...de interés nacional la atención y apoyo a los aborígenes y a las comunidades existentes en el país, y a su defensa y 
desarrollo para su plena participación en el proceso socioeconómico y cultural de la Nación, respetando sus propios valores y modalidades (art. 1).

Esta norma creó, además, el Instituto Nacional de Asuntos Indígenas (INAI) como una entidad descentralizada que debe llevar un Registro de Comunidades Indígenas -a las que se les otorga personería jurídica-y elaborar planes de adjudicación y explotación de tierras, de educación y de salud. Se prevé la participación de estas comunidades en la implementación de la ley a través del envío de representantes a un Consejo de Coordinación de carácter consultivo (Dec. 155/89 arts. 7 i y 10).

En 1992 Argentina ratificó por Ley $24.071 \mathrm{el}$ Convenio 169 de la OIT aunque el instrumento de ratificación se depositó recién en el 2000, año en el cual adquirió jerarquía constitucional en virtud del art. 31 de la CN. Este convenio no sólo coincide con el criterio de autorreconocimiento étnico adoptado por la Ley 23.302 como base para la definición de los pueblos indígenas, sino que establece que los gobiernos deben "asumir la responsabilidad de desarrollar, con la participación de los pueblos interesados, una acción coordinada y sistemática con miras a proteger los derechos (sociales, económicos y culturales) de esos pueblos y a garantizar el respeto de su integridad" (art. 2.1, también 2.b). Asimismo se dispone que "deberán protegerse los valores y prácticas sociales, culturales, religiosas y espirituales propios de dichos pueblos (...)" (art. 6).

Finalmente la Constitución Nacional reformada en 1994, en su art. 75 inc. 17, reconoce "la preexistencia étnica y cultural de los pueblos indígenas argentinos", garantizando -concurrentemente con las provincias- "el respeto a su identidad y asegurando su participación en la gestión referida a sus recursos naturales y a los demás intereses que los afecten". Este último párrafo ha sido interpretado como una admisión implícita al derecho de participar en la gestión del patrimonio cultural de sus antepasados (Endere 2000a:56).

Como se observa existe un reconocimiento significativo a los pueblos indígenas en las normas de mayor jerarquía de Argentina. Sin embargo, esos derechos no siempre son contemplados en la legislación derivada -nacional o provincial- y mucho menor aún es su grado de observancia en la práctica.

\section{Reclamos indígenas sobre el patrimonio cultural en Argentina}

El reconocimiento legal de las comunidades indígenas de Argentina en las últimas décadas cambió considerablemente las perspectivas de los reclamos sobre restos humanos que formaban parte de colecciones de museos. El caso paradigmático lo constituye el Museo de La Plata que alberga una colección de esqueletos y cráneos, fundamentalmente tehuelches y araucanos que perecieron o fueron tomados prisioneros durante la "Conquista del Desierto" (Podgorny y Politis 1992; Quijada 1998). Estos esqueletos, sobre todo los restos de caciques de conocida trayectoria histórica, han sido reclamados por diferentes grupos y descendientes desde los años setenta. Sus reclamos fueron denegados porque los restos integraban colecciones arqueológicas consideradas como bienes del dominio público del Estado, en virtud de lo dispuesto en el art. 2340 inc. 9 del Código Civil. En otros casos, el rechazo se fundó en la imposibilidad de probar legalmente el parentesco por consanguinidad (Endere 2000b, 2002). Dadas las circunstancias, la restitución solo sería posible si se dictara una ley que los desafectara del dominio público. En 1991 se dictó la primera Ley de Repatriación (23.940/91) que ordenó la restitución del cacique tehuelche Inakayal a su lugar de origen, en Tecka, Chubut, donde fue enterrado en un mausoleo en 1994 después de recibir honores militares y rituales indígenas. Una nueva restitución se produjo gracias a la Ley 25.276/2001 que ordenó la devolución de los restos del jefe Ranquel Mariano Rosas (Panghitruz Güor) a la comunidad ranquelina o Rankülche que habita en la provincia de La Pampa (Endere y Curtoni 2006), hecho que sin duda marcó un hito en el resurgimiento de esta comunidad y en la "representación del Rankülche como entidad étnica en vías de regreso" (Lazzari 2003, 2010).

Finalmente la Ley 25.517/01 intentó generar un cambio sustancial en la materia, al establecer que los museos deben poner a disposición de "los pueblos indígenas o comunidades de pertenencia que los reclamen" los restos humanos de aborígenes que formen parte de sus colecciones (art. 1). Asimismo exige que "para realizarse todo emprendimiento científico que tenga por objeto a las comunidades aborígenes, incluyendo su patrimonio histórico y cultural, deberá contarse con el expreso consentimiento de la comunidad interesada" (art. 3). Esta 
norma, sin embargo, no establece los requisitos que deben cumplir las comunidades para efectuar sus reclamos, el criterio que deben seguir los museos para hacer lugar a los mismos, ni la forma de dirimir los eventuales conflictos. Esta norma requiere la adhesión de las provincias para que sea aplicable en sus territorios. Por ello, la provincia de Río Negro sancionó en el 2001 la Ley 3.468 que adhiere a la Ley 25.517 y establece que la comunidad que realice el reclamo deberá estar reconocida en su jurisdicción de origen o contar con aval de organismo oficial que certifique su existencia, subsanando de este modo la cuestión de definir qué se entiende por "comunidad de pertenencia".

Pasaron varios años sin que esta ley fuera reglamentada, durante ese período se sancionó en el 2003 la Ley Nacional 25.743 de Protección del Patrimonio Arqueológico y Paleontológico. Esta norma distribuye competencias entre el Estado nacional y las provincias y establece que la autoridad de aplicación a nivel nacional es el Instituto Nacional de Antropología y Pensamiento Latinoamericano (INAPL), al tiempo que crea el Registro Nacional de Yacimientos, Colecciones y Objetos Arqueológicos. Sin embargo, no menciona a las comunidades indígenas ni establece ninguna diferenciación entre los sitios arqueológicos ubicados en tierras indígenas y los que se encuentran en propiedad privada. Esta ley fue criticada por diferentes agrupaciones indígenas que alegaron su inconstitucionalidad, aunque no se han efectuado presentaciones judiciales al respecto. La Ley 23.743 fue sancionada después de un errático proceso legislativo y su sanción generó no pocas polémicas en algunos investigadores y asociaciones profesionales que reclamaron la falta de participación en su elaboración.

En mayo de 2010 y como resultado de una multitudinaria marcha de los pueblos originarios a la Plaza de Mayo, el gobierno anunció algunas medidas, entre ellas la reglamentación de la Ley 25.517 mediante el Decreto 701 que establece que el Instituto Nacional de Asuntos Indígenas (INAI) "será el encargado de coordinar, articular y asistir en el seguimiento y estudio del cumplimiento de las directivas y acciones dispuestas por la Ley 25.517". El INAI está facultado para "efectuar relevamientos tendientes a identificar los restos mortales de aborígenes que formen parte de museos y/o colecciones públicas o privadas y propiciar su restitución", coordinando sus acciones con los organismos competentes en la materia, en especial con el Instituto Nacional de Antropología y Pensamiento Latinoamericano". Asimismo podrá "recabar informes y emitir opinión sobre los emprendimientos científicos que tengan por objeto a las comunidades aborígenes, contemplados en el artículo $3^{\circ}$ de la Ley 25.517". Cabe destacar que este decreto autoriza a los organismos de investigación que tuvieran en su posesión restos mortales reclamados, a solicitar una prórroga de hasta de 12 meses para concretar su devolución.

\section{Estándares de ética profesional}

La posibilidad de constituir un colegio profesional de arqueólogos con control de la matrícula ha sido largamente debatida en Argentina, aunque los resultados no han sido demasiado alentadores. Ello se debe a que la competencia para crear colegios profesionales es provincial, por lo que debe crearse uno por provincia ${ }^{5}$. De modo que si un profesional trabaja en más de una provincia, cuestión bastante usual, deberían matricularse en cada una de ellas, aumentando los costos del ejercicio profesional. Es por ello que en 1999 se creó una asociación civil de integración voluntaria denominada AAPRA (Asociación de Arqueólogos Profesionales de la República Argentina).

En la última década se ha avanzado, aunque de manera menos orgánica, en la discusión de temas relacionados con los derechos indígenas en diferentes reuniones de especialistas. Un ejemplo de ello lo constituye la mesa redonda efectuada en la Universidad de Salta en 1999, con el objeto de discutir las implicaciones éticas del hallazgo de momias en el Volcán Llullaillaco ${ }^{6}$. Entre las recomendaciones adoptadas en dicha reunión se enfatizó la necesidad de que la legislación y las autoridades políticas tengan en cuenta los derechos e intereses de las comunidades locales y de los pueblos indígenas a participar en el manejo del patrimonio cultural (ap.1. d). También se señaló la necesidad de "promover la adopción de reglas de conducta profesional donde se contemplen los aspectos éticos de los arqueólogos frente a los hallazgos y al destino posterior de las colecciones (...), los derechos de las comunidades locales y pueblos indígenas a participar en la toma de decisiones en la gestión del patrimonio", así como de "reconocer el aporte que la arqueología puede hacer al conocimiento del pasado y en particular del patrimonio cultural indígena” (ap. 2. b), (CEPIHA 1999). 
En mayo de 2005 se firmó la "Declaración de Río Cuarto" en el marco del Primer Foro ArqueólogosPueblos Originarios realizado en la ciudad de Río Cuarto, Córdoba y convocado por mandato del Plenario del XV Congreso Nacional de Arqueología Argentina. Las recomendaciones de esta declaración versan sobre los siguientes aspectos:

(a) la no exhibición de restos humanos que se encuentren en museos, así como la necesidad de sensibilizar al público acerca de las razones que fundamentan dicha decisión;

(b) el respeto por la sacralidad ancestral de los restos humanos y sitios indígenas, y la necesidad de adecuar las técnicas y procedimientos arqueológicos para hacerlos compatibles con dicho respeto;

(c) la colaboración mutua para lograr la restitución de restos humanos indígenas que estén alojados en colecciones públicas y/o privadas, así como la modificación de la actual ley de patrimonio arqueológico;

(d) la necesidad de que los arqueólogos valoren responsablemente las consecuencias sociales y políticas de la investigación arqueológica, en relación a los derechos de las comunidades indígenas y

(e) Contar con el acuerdo previo de las comunidades indígenas para la realización de investigaciones arqueológicas y de extremar los recaudos para que éstas cuenten con la información relevante para la toma de decisiones.

Esta declaración si bien no recibió en su momento muchas adhesiones, generó un impacto más bien doctrinario tanto en investigadores como en representantes indígenas (ver Canuhé 2005; Pérez Gollán 2005).

En el 2007 la Asociación de Antropología Biológica Argentina (AABA) aprobó una Declaración en relación con la Ética del Estudio de Restos Humanos. Este código fue adoptado por los miembros de la asociación en defensa de sus derechos frente a los reclamos de las comunidades indígenas. Si bien reconocen "la lucha secular de los pueblos originarios" sostienen que "el estudio científico de los restos biológicos humanos es de interés para toda la humanidad" (art. 2) y afirman el derecho de la AABA a participar en toda discusión referida a la gestión y manejo del patrimonio biocultural, incluidos los restos humanos (art. 4). No obstante, reconocen que "es deseable facilitar la restitución de restos de identidad conocida a las comunidades de pertenencia que los reclamen -siendo materia de discusión la restitución de los otros restos-, así como atender a los reclamos de no exhibición pública de restos humanos en museos (arts. 5 y 6). Finalmente promueve la formación y actuación de una comisión ad hoc destinada a la redacción de un Código de Ética y la fijación de criterios básicos para posibilitar un diálogo con los diferentes actores sociales involucrados y asesorar a los cuerpos legislativos que lo requieran (art. 4). Sin embargo, esta declaración -a diferencia de la Vermillion y de la de Río Cuarto- fue elaborada y aprobada sin la participación de representantes indígenas.

En septiembre de 2009 la AAPRA aprobó un Código de Ética Profesional destinado a sus asociados. En el mismo se establece que:

Art. 4. Es deber de los arqueólogos no sólo respetar sino hacer respetar y difundir todas las leyes y disposiciones legales nacionales y provinciales y las recomendaciones internacionales relacionadas con el patrimonio arqueológico.

Art. 14. Los restos humanos deben ser tratados con particular respeto, atendiendo a criterios consensuados entre los distintos actores sociales interesados.

Art. 15. Se deberá promover una interacción positiva con las comunidades locales directamente ligadas al área de investigación, independientemente de su origen étnico, respetando sus preocupaciones, costumbres, credos y valores, en la medida en que esto no implique incurrir en actos ilegales ni contradecir este código o los derechos fundamentales de cualquier ser humano. Art. 16. Los resultados de las investigaciones arqueológicas se deben dar a conocer públicamente en un lapso razonable y en la mayor cantidad posible de ámbitos.

Como puede observarse, este código aunque sin mencionarlo expresamente tiene en cuenta las comunidades indígenas aun cuando sus disposiciones son bastante limitadas, en particular en relación a la cuestión de los restos humanos.

En general todos estos principios y declaraciones parecen operar como meras expresiones de deseos que no tienen demasiadas implicancias en la práctica profesional. Es por ello que quizás haya resultado más operativa la cláusula sobre recaudos 
éticos basada en la Ley 25.517 que ha incluido el Consejo Nacional de Investigaciones Científicas y Tecnológicas (CONICET) entre los requisitos para acceder al financiamiento de proyectos o para la aprobación de planes de trabajo. Cabe destacar que el CONICET creó en 2005 el Comité de Ética como un órgano interdisciplinario de asesoramiento sobre aspectos éticos y bioéticos vinculados al desarrollo de actividades científicas en dicho organismo. Este Comité produjo dos documentos que fueron adoptados por el CONICET: "Principios éticos para el comportamiento del investigador científico y tecnológico" (Res 540/2006) y "Lineamientos para el comportamiento ético en las Ciencias Sociales y Humanidades" (Res 2857/2006). Entre dichos principios se contempla la obligación de obtener el consentimiento libre e informado de los participantes en proyectos científicos, de respetar los restos humanos involucrados en las investigaciones y de no participar en trabajos que puedan afectar los derechos humanos reconocidos por los convenios internacionales y la Constitución Nacional. En ese marco se incluyó en los Informes de Investigador o pedidos de subsidios de CONICET un acápite relativo a "Aspectos éticos" en donde el investigador debe responder de manera afirmativa o negativa respecto de: a) si la propuesta o plan de trabajo debe ser analizado desde el punto de vista ético y b) si comprende "Estudios de comunidades aborígenes (ver Ley 25.517)".

El reconocimiento que los derechos indígenas han tenido en el ámbito legal y en los códigos de ética profesionales parecen haber generado un impacto desigual entre los investigadores, cuyas actitudes podrían resumirse en cuatro tipos básicos: los que se niegan y resisten (aunque cada vez menos abiertamente), los que aceptan pero no cambian sus metodologías de trabajo, los que tienen un discurso claramente reivindicativo e intentan aplicarlo en sus prácticas profesionales y los que adoptan una militancia activa en beneficio de los indígenas (ver Verdesio 2010:133). En esta última categoría podría ubicarse la actividad del Grupo Universitario de Investigación en Antropología Social (GUIAS) que denunció públicamente en 2006 que aún se encontraban en el Museo de La Plata el cuero cabelludo y el cerebro de Inakayal ${ }^{7}$ (ya que hallaron restos identificados con los números de inventario otorgado en su oportunidad). Este grupo identificó además restos de 35 personas que se encontraban en las colecciones del Museo de La Plata, lo cual permitió que, una vez comprobada su identidad por antropólogos biólogos, se generaran nuevos pedidos de restitución y se concretara la devolución de "Damiana" y otro individuo a la comunidad Aché de Paraguay en el 2010 (Pepe et al. 2008, también Ametrano 2010).

Otro caso para destacar son las investigaciones desarrolladas por un equipo franco-argentino en el Museo de Quai Branly, París, con el objeto de desclasificar en sus depósitos los restos óseos de "gigantes patagones" exhumados por el conde Henry de La Vaulx en la Patagonia entre 1896 y 1897. Como señala Vezub, esta investigación pone de manifiesto una "epistemología colonial" -común en los museos de la época- de fragmentar partes del cuerpo y la documentación correspondiente en diferentes colecciones, por lo que "desclasificar" consiste en reconectar "restos, objetos, imágenes y textos de escasa visibilidad, la identificación de quiénes y de dónde provienen, las referencias geográficas de las sepulturas, la individualización de las osamentas y los ajuares funerarios". En suma, "conectar a los restos con su historia, invirtiendo el trabajo de campo (...) y concebir al museo como el terreno arqueológico para desandar una historia y una historiografía" (Vezub 2009:3-4).

Cabe mencionarse también investigaciones antropológicas que analizan conflictos entre comunidades indígenas e instituciones académicas en el marco de procesos de re-emergencia étnica, en los cuales los restos humanos ocupan un capítulo importante en la lista de reclamos. Es el caso, por ejemplo, de la Comunidad Huarpe de la provincia de San Juan que desafiando a los arqueólogos regionales que afirman su inautenticidad biológica, histórica y cultural, piden la restitución de restos humanos al Instituto de Investigaciones Arqueológicas y Museo de la Universidad de San Juan, en especial de la Momia de Los Morillos (Escolar 2007; Jofré et al. 2010).

Finalmente, no puede dejar de destacarse que varios museos nacionales de Argentina han decidido retirar de exhibición las momias u otros restos humanos, siendo el Museo Etnográfico de la Universidad de Buenos Aires el cual asumió un rol de liderazgo en la materia. Este museo, además, devolvió voluntariamente en el 2004 una cabeza momificada de un guerrero maorí que formaba parte de sus colecciones desde 1910, entregándola al Museo Nacional Te Papa de Nueva Zelanda hasta que se determine su procedencia a fin de entregarla a los descendientes. 


\section{El Caso de los Pueblos Indígenas y el Patrimonio en Chile}

Desde su creación en 1810 hasta principios de la década de los noventa, el Estado chileno tuvo una política de negación étnica, integración y asimilación de las poblaciones indígenas que habitaban el territorio nacional. Ya en tiempos de O'Higgins se identifica la idea de su asimilación étnica-jurídica-política, tal como se evidencia en el decreto de 3 de junio de 1818, en el cual al cambiar la denominación "español" por la de "chileno", se plantea que no "debe hacerse diferencia alguna (de los indios), sino denominarlos chilenos" (González 2005:80). El período comprendido entre 1882 y 1924 fue especialmente crítico para los pueblos originarios y el mantenimiento de su cultura, siendo las "reducciones" en el sur el mecanismo elegido para la fragmentación de las comunidades mapuches. Durante la primera mitad del siglo XX, el tema indígena empezó paulatinamente a articularse en las políticas públicas y sociales sobre pobreza, regularización de títulos de dominio o en la promoción de agencias que cautelaran los derechos indígenas. En este contexto, en 1930 se creó la Ley 4.802 a través de la cual cinco Juzgados de Indios "procederían de oficio a dividir las comunidades indígenas que tengan título de merced" y, hacia 1953 se creó la Dirección de Asuntos Indígenas, con lo cual se asumió el denominado "indigenismo estatal" al igual que en otros países latinoamericanos.

En 1972 durante el gobierno de la Unidad Popular se aprobó la primera Ley Indígena (17.729) del país, la cual reconoció la existencia de comunidades culturalmente diferenciadas, asumiendo una deuda histórica con estos pueblos y entregando algunas luces sobre su participación política. Sin embargo, pese a que estas medidas lograron darle cierta visibilidad a las organizaciones indígenas especialmente mapuches, el proceso que impulsó fue abruptamente detenido y contrarrestado con el golpe militar de 1973 (Bolados 2010). Durante la dictadura la situación indígena se retrotrajo a la noción de la propiedad privada y se forjó una nueva institucionalidad.

El Decreto Ley 2.568 de 1978 sobre división de las reservas rezaba que "dejarán de considerarse tierras indígenas e indígenas sus dueños y adjudicatarios". Su tremendo impacto llevó a su reforma por el Decreto Ley 2.750 de 1979, modificación radical donde el Estado benefactor se deshacía y emergía el mercado como el orientador de las asignaciones de agua y la configuración de la propiedad (González 2005:85). Las consecuencias de estas normativas en el mundo indígena fueron devastadoras, llegándose a considerar dichos Decretos como la "legislación etnocida del régimen militar" (Aylwin 1989).

En 1989 se inicia un proceso de cambio en la relación del Estado con los pueblos indígenas en Chile cuando este tema es abordado por la Concertación de Partidos por la Democracia. En este contexto surge el acuerdo de Nueva Imperial, con Patricio Aylwin como candidato presidencial, quien se compromete a la creación de una Comisión Especial de Pueblos Indígenas (CEPI) con la participación de representantes de dichas colectividades. Esta comisión tenía la tarea de proponer el reconocimiento constitucional de los pueblos indígenas y de promover una legislación que favorezca su desarrollo. De este modo, se elaboró una propuesta de ley que fue aprobada por unanimidad por el Congreso de la República, promulgándose así la Ley Indígena 19.253 en 1993. En ella se reconoce como principales etnias indígenas de Chile a las Mapuche, Aimara, Rapa Nui o Pascuenses, Atacameños, Quechuas, Collas, Kawashkar o Alacalufe y Yámana o Yagán.

En esta ley, específicamente en el Título IV, De la Cultura y Educación Indígena, Párrafo $1^{\circ}$, Del Reconocimiento, Respeto y Protección de las Culturas Indígenas, los artículos 28 y 29 se refieren al patrimonio cultural y arqueológico en los siguientes términos:

Art. 28.- El reconocimiento, respeto y protección de las culturas e idiomas indígenas contemplará: f) La promoción de las expresiones artísticas y culturales y la protección del patrimonio arquitectónico, arqueológico, cultural e histórico indígena. Art. 29.- Con el objeto de proteger el patrimonio histórico de las culturas indígenas y los bienes culturales del país, se requerirá informe previo de la Corporación para: a) La venta, exportación o cualquier otra forma de enajenación al extranjero del patrimonio arqueológico, cultural o histórico de los indígenas de Chile. b) La salida del territorio nacional de piezas, documentos y objetos de valor histórico con el propósito de ser exhibidos en el extranjero. c) La excavación de cementerios históricos indígenas con fines científicos la que se 
ceñirá al procedimiento establecido en la Ley 17.288 y su reglamento, previo consentimiento de la comunidad involucrada..."

La promulgación de esta ley conllevó la creación de la Corporación Nacional de Desarrollo Indígena (CONADI), como una institución estatal especializada en atender las problemáticas de estas poblaciones. Su misión es promover, coordinar y ejecutar la acción del Estado en favor del desarrollo integral de las personas y comunidades indígenas, especialmente en lo económico, social y cultural, además de impulsar su participación en la vida nacional. Una de sus funciones es "velar por la preservación y la difusión del patrimonio arqueológico, histórico y cultural de las etnias" (art. 39), coincidiendo así con las atribuciones del Consejo de Monumentos Nacionales (CMN), organismo encargado del registro, protección, conservación y difusión del patrimonio nacional desde 1925. Si bien inicialmente las acciones de estas instituciones no estaban coordinadas a la hora de ejecutar los proyectos patrimoniales desarrollados en territorios indígenas (Ayala 2008 y 2009), esto cambia en 2001 con la apertura del Área de Patrimonio Cultural de los Pueblos Indígenas en el CMN, lo cual se justificó en los siguientes términos:

...se ha hecho necesario ampliar la mirada e incluir el legado vivo e intangible de los pueblos originarios en el patrimonio cultural de carácter monumental de la nación, debido a que el Estado ha avanzado en la comprensión en el marco de los derechos culturales patrimoniales de nuestros pueblos, como elementos positivos que enriquecen el acervo cultural de la nación (sitio web: www.monumentos.cl).

Si bien la apertura de esta área en el Consejo ha sido un paso importante hacia el reconocimiento de los derechos de los pueblos indígenas sobre su patrimonio, la Ley de Monumentos Nacionales 17.288 no ha sufrido ningún cambio en este sentido. En efecto, a pesar de que esta institución afirma reconocer el vínculo de las poblaciones originarias con el patrimonio arqueológico, en la Ley de Monumentos Nacionales los indígenas siguen siendo tratados como cualquier ciudadano chileno, ya que no reconoce las particularidades y derechos culturales de estas poblaciones. Asimismo, esta ley resguarda el control y propiedad estatal del patrimonio arqueológico:

...por el solo ministerio de la ley son Monumentos Arqueológicos de propiedad del Estado los lugares, ruinas, yacimientos y piezas antropo-arqueológicas que existen sobre o bajo la superficie del territorio nacional... (Título $\mathrm{V}$, art. 21).

A lo que se suma el art.1 que explicita que también son Monumentos Nacionales:

...los enterratorios o cementerios u otros restos de los aborígenes, las piezas u objetos antropo-arqueológicos, paleontológicos o de formación natural, que existan bajo o sobre la superficie del territorio nacional o en la plataforma submarina de sus aguas jurisdiccionales y cuya conservación interesa a la historia, al arte o a la ciencia.

Según ello, al igual que los objetos arqueológicos, los restos humanos encontrados en sitios de este tipo son Monumentos Nacionales de propiedad estatal. En consecuencia, para el CMN las comunidades indígenas tienen derecho a reclamar los restos humanos como antepasados, al igual que todos los chilenos, siendo una cuestión aparte que puedan acceder legalmente a ellos, ya que es sólo de competencia del Estado (Ayala 2008).

En este contexto, hasta la fecha los proyectos y demandas patrimoniales de las poblaciones indígenas han sido abordados por el CMN con acuerdos o convenios circunscritos a casos específicos, los que si bien sirven de referentes en el tratamiento de estas materias no constituyen una postura oficial al respecto ni conforman una norma de tipo general. Junto con esto, según las particularidades del caso, el CMN plantea "sugerencias" al accionar científico frente a la temática indígena, siendo una de ellas la de "informar" a las comunidades sobre la realización de una investigación, en el entendido de que esto no se trata de una obligación y de que la "autorización" propiamente dicha le corresponde exclusivamente al Estado.

Es de esperar que la reciente puesta en vigor en Chile del Convenio 169 de la OIT sobre pueblos indígenas y tribales, el 15 de septiembre de 2009, después de permanecer dieciocho años en el Congreso Nacional, promueva cambios sustanciales 
en la legislación patrimonial vigente. Sin embargo, los intentos del Estado por cancelar internamente los derechos de los pueblos indígenas reconocidos a nivel internacional -tratando de adicionar una "Declaración Interpretativa" de este convenio y promulgando un "Reglamento de Consulta y de Participación de los Pueblos Indígenas de Chile" que lo vulnera- nos llevan a pensar que las transformaciones requeridas no se realizarán en un corto plazo. A ello se suma un contexto disciplinario en el cual la temática indígena es marginal en relación, por ejemplo, a los proyectos de impacto ambiental.

\section{Reclamos indígenas sobre el patrimonio cultural en Chile}

Los cambios producidos por la política multicultural implementada en Chile, así como las consecuentes innovaciones legales e institucionales desarrolladas desde principios de los años noventa, generaron un contexto propicio para los reclamos indígenas vinculados con el patrimonio cultural y la arqueología. Así como en el sur del país líderes mapuches expresaron sus críticas en el Congreso Nacional de Arqueología realizado en Temuco en 1993, en el norte dirigentes atacameños manifestaron sus cuestionamientos al Museo Arqueológico de San Pedro de Atacama y a la práctica arqueológica local, en reuniones organizadas tanto por miembros de esta etnia como por profesionales de la disciplina (Ayala 2008, 2009).

Uno de los casos más paradigmáticos en este sentido es el de la etnia atacameña, no solo por ser uno de los más visibles e investigados, sino por corresponder a la primera agrupación que planteó una serie de demandas patrimoniales ante el Estado y los arqueólogos. Una síntesis de sus reivindicaciones permite afirmar que estas no solo se refieren a su oposición a la excavación de cementerios arqueológicos y exhibición de cuerpos humanos, sino también a demandas de entrega de información, de solicitud de permiso comunitario para investigar, de participación en el quehacer disciplinario, de administración de los sitios y el museo local y de propiedad de los vestigios arqueológicos (Ayala 2007, 2008). Si bien no se cuenta con una sistematización de las demandas patrimoniales de otras agrupaciones étnicas de Chile, reclamos relacionados con los restos humanos indígenas ${ }^{8}$ también han sido planteados por mapuches (Paillalef 2008) y pascuenses (Seelenfreund 2008).
En cuanto al tratamiento jurídico relacionado con los restos óseos indígenas en Chile, concordamos con González (2008:151) en que “....existe todavía un largo camino que recorrer en esta materia, dado que la legislación existente es vaga, incompleta y confusa". En efecto, en relación al reclamo étnico de no excavar cementerios, la Ley Indígena establece que sólo la excavación de cementerios indígenas históricos requiere la autorización de las comunidades e informe previo de la CONADI al CMN (art. 29, Letra c). Sin embargo, tal como lo plantea esta autora (2001:183-184), ni este cuerpo legal ni la Ley de Monumentos Nacionales 17.288 definen un criterio para discernir cuándo estamos frente a un cementerio histórico que requiera para su excavación el consentimiento de la comunidad indígena afectada y cuándo ante un cementerio de exclusiva competencia del CMN. El punto de discriminación estaría en el uso actual, por lo que un cementerio cuya data no exceda del período republicano y que no tenga un uso contemporáneo, cae dentro del ámbito de la Ley 17.288, considerándose Monumento Arqueológico, de propiedad del Estado, por el solo ministerio de la ley. En tanto, los restos humanos indígenas presentes en cementerios posteriores al período republicano que cuenten o no con un uso actual caen dentro del ámbito de competencia del Servicio Nacional de Salud y su exhumación debe ceñirse a las normas pertinentes del Código Sanitario y el Reglamento General de Cementerios. Siguiendo este argumento, la excavación de cementerios históricos indígenas con fines científicos requerirá informe previo de la CONADI y autorización de la comunidad indígena involucrada cuando sean posteriores al período republicano y exista una vinculación evidente con la comunidad de que se trate. Esto, sin perjuicio de la competencia general del Servicio Nacional de Salud (González 2001:185).

A esto podría sumarse un criterio de diferenciación más amplio entre cementerios prehispánicos e históricos, quedando en este caso sólo los primeros exentos de consentimiento comunitario. Pese a la ambigüedad legislativa queda claro que para el Estado chileno existen cementerios indígenas que pueden excavarse sin la autorización de la comunidad involucrada y que requieren solamente del permiso del CMN. Si bien es cierto que la excavación de cementerios históricos puede afectar más directamente a estas poblaciones que la exhumación de cuerpos prehispánicos, también lo es que el Estado 
desconoce el vínculo establecido por los indígenas con estos restos humanos como antepasados, al no solicitar legalmente su autorización para las excavaciones arqueológicas.

En relación a la demanda de no exhibir cuerpos humanos en los museos, no existe en Chile un criterio legal que apoye o refute esta reivindicación indígena. Sin embargo, esta ha sido manifestada por los atacameños en diversos encuentros y foros locales, así como en documentos presentados a distintas instituciones, alcanzando su mayor formalidad con la publicación del Informe Final de la Comisión de Trabajo sobre el Pueblo Atacameño de la Mesa de Verdad Histórica y Nuevo Trato del 2003, en el cual se plantea una demanda sobre reconocimiento, respeto y fomento de la cultura atacameña: "h) Legislar a favor del cuidado, protección y exhibición del material cultural en los museos, prohibiendo la exhibición de cuerpos".

Dicho informe se constituyó en el soporte definitivo para que el Museo Arqueológico de San Pedro de Atacama decidiera retirar los cuerpos humanos de su exhibición permanente, considerando también para ello los principios éticos del código de Deontología del ICOM. Para dar forma a esta decisión y con la finalidad de delinear, discutir y acordar el proceso mediante el cual ésta se materializaría, en 2006 se constituyó la "Mesa de Trabajo para el retiro de los cuerpos y restos humanos arqueológicos de exhibición". Esta instancia fue convocada por el Museo y conformada por representantes del Consejo de Pueblos Atacameños, miembros de algunas comunidades indígenas, funcionarios atacameños de la institución y profesionales del museo. Se reunieron intermitentemente durante 10 meses para tratar de consensuar una nueva propuesta museográfica y programar las fechas y procedimientos adecuados para el proceso de retiro. La remoción de los cuerpos humanos se concretó en mayo del 2007, la cual fue seguida de una ceremonia oficiada por miembros de la comunidad atacameña dirigida a sus antepasados, al tiempo que todos los restos humanos de la exhibición se limpiaron y dispusieron en un depósito exclusivamente construido para el efecto, considerando para ello conceptos como dignidad, intimidad y descanso (Sepúlveda et al. 2008; Sepúlveda y Ayala 2009).

En esta mesa de trabajo se concluyó que el retiro de los cuerpos humanos es un "primer paso" a favor del respeto de las demandas patrimoniales atacameñas. Sin embargo, al igual que en otras instancias de discusión se reiteró la solicitud de reentierro de los restos humanos depositados en este Museo, a pesar de que aún es un tema en discusión al interior de la propia comunidad. Desde su perspectiva académica y museológica los profesionales de esta institución defienden la idea de que el patrimonio arqueológico y bioantropológico debe estar al servicio de la investigación y difusión, resguardado por principios generales de conservación. Por ello, no consideran el reentierro como una opción por el momento, aunque ocasionalmente mencionan otras posibilidades que podrían dar respuesta a las distintas visiones involucradas.

Sobre este tema cabe mencionar que Chile no tiene una ley referente a la reinhumación, sin embargo, actualmente el CMN cuenta con un "Instructivo orientador para el reentierro de restos humanos provenientes de contextos arqueológicos, a petición de comunidades y organizaciones". De acuerdo a este documento, en su versión de diciembre de 2009, se debe reenterrar específicamente:

Por solicitud de comunidades indígenas (reconocidas por la Ley Indígena, con vinculación comprobable (cultural y geográfica) con los restos arqueológicos en cuestión), solicitud que deberá contemplar la aplicación del Convenio 169 de la OIT, en particular los procesos de participación, cooperación y consulta que él dispone.

Por solicitud de una organización nacional, regional o local (indígena, científica, etc.), que fundamente legal (Ley Indígena u otra) y científicamente la necesidad de reentierro de determinados restos bioantropológicos.

Salvaguardando las colecciones museológicas existentes en el país, este instructivo plantea que los criterios considerados para evaluar los casos de reentierro "se refieren a hallazgos arqueológicos nuevos y no a las colecciones actualmente en depósito en los museos".

Con anterioridad a la elaboración de este documento el CMN autorizó el cambio de lugar de entierro de cuerpos sepultados en iglesias de Chiloé que son Monumentos Históricos (Ayala 2008). Asimismo, como parte del primer proceso de repatriación realizado en Chile, autorizó el reentierro de restos humanos prehispánicos en 
Arica y Chiu Chiu. Su realización estuvo sujeta a un convenio firmado entre el National Museum of the American Indian (NMAI) y CMN, así como en base a un acuerdo entre esta última institución y las comunidades involucradas. En este contexto, el CMN se comprometió a respaldar y facilitar el retorno de restos humanos a las comunidades indígenas a las que estén "culturalmente afiliadas" (González 2008).

A diferencia de lo ocurrido en otros países donde son las organizaciones indígenas las que inician este proceso, en este caso fue el NMAI del Smithsonian el que planteó la posibilidad de repatriar restos humanos provenientes del norte de Chile. A través de su departamento de repatriación, dicha institución se contactó con el CMN, la CONADI y representantes de las etnias aymara y atacameña para coordinar reuniones y visitas, sobre todo considerando las diferencias legislativas entre Estados Unidos y Chile. Posteriormente, siguiendo las exigencias de la Ley NAGPRA, dichas agrupaciones indígenas presentaron la solicitud de repatriación correspondiente al NMAI. Después de casi dos años de conversaciones, en 2007 se llevó a cabo la repatriación desde Estados Unidos de restos momificados originarios de Atacama y Arica, proceso en el cual participaron la comunidad atacameña de Chiu Chiu y la comunidad aymara Pacha Aru, ya que se asumió su vínculo cultural con dichos restos óseos. En ambos casos el reentierro se realizó en asociación a sitios arqueológicos.

\section{Estándares de ética profesional}

Desde 1963 la instancia que agrupa a la mayoría de los arqueólogos en Chile es la Sociedad Chilena de Arqueología (SCHA), la cual funciona como el órgano de representación oficial de estos profesionales ${ }^{9}$. El código de ética de la SCHA fue elaborado a mediados de los años noventa, fundamentalmente debido a la necesidad de normar los estudios de impacto ambiental que comenzaban a perfilarse como una de las actividades más relevantes en el quehacer arqueológico del país. Si bien en esos momentos la temática indígena tenía una alta visibilidad a nivel nacional e internacional, este código se refiere de manera general a estas poblaciones y no aborda sus demandas patrimoniales en particular. No obstante, cuenta con puntos que tocan directa o indirectamente esta problemática. En este sentido, uno de sus objetivos plantea:
2.2 Velar por el respeto a la legislación vigente, especialmente en lo que concierne al campo de la arqueología y antropología chilena (Ley 17.288 sobre Monumentos Nacionales y Ley Indígena; y a los recientes o nuevos reglamentos referidos a los estudios de impacto ambiental (Ley 19.300 sobre Bases del Medio Ambiente).

Asimismo, en el acápite de Compromisos de los Arqueólogos, en el punto 3.1 con el o los Objetos de Estudio, menciona: "3.11 Referirse con el mayor respeto al mencionar las comunidades indígenas tanto pretéritas como actuales cuyos vestigios han sido o son objeto de nuestros estudios". En el punto 3.2 Con la Sociedad en General afirma:

3.2.1. Propiciar y mantener una interrelación fluida con la sociedad en general y determinadas comunidades en particular, respetando los diversos grupos étnicos que la componen y sus particulares formas de expresión cultural.

3.2.2. Reconocer y comunicar la importancia de estudiar, conservar y difundir la herencia cultural indígena, así como respetar sus restos patrimoniales, tal como lo prescribe la legislación vigente.

3.2.3. Solicitar el consentimiento o comunicar personalmente, en forma previa a la ejecución de los estudios y con la certificación de una copia de los correspondientes permisos otorgados por el Consejo de Monumentos Nacionales, a cada particular, comunidad local o comunidad indígena, en cuyos terrenos se efectuarán las investigaciones.

3.2.4. Procurar poner a disposición del público en general, en forma veraz y responsable y como un aporte al conocimiento del pasado, a la cultura y a la ciencia, la información resultante del quehacer arqueológico. En el caso de las comunidades étnicas en particular, comunidades locales y propietarios individuales, se deberá entregar en cada caso una copia o un resumen de la información obtenida de las investigaciones realizadas en sus territorios o propiedades.

Pese a la existencia de estos principios éticos no todos los miembros de esta sociedad parecen 
estar al tanto de los mismos y cumplir con sus planteamientos, siendo un ejemplo en este sentido la negación de algunos arqueólogos a solicitar permiso comunitario para investigar, ya que desde su perspectiva es suficiente con la autorización del CMN. Junto con esto, sigue siendo una práctica poco común entregar la información recopilada a las comunidades indígenas, así como la participación de sus miembros en los proyectos arqueológicos. Por otro lado, a pesar de no existir un pronunciamiento oficial de esta sociedad acerca del tratamiento de los cuerpos humanos, al menos en el norte del país se observa una tendencia a dejar de excavar cementerios arqueológicos y retirar los cuerpos humanos de las exhibiciones. Siendo diferente la posición de los arqueólogos frente a temas más controvertidos como el reentierro, la repatriación y la propiedad del patrimonio arqueológico, ya que en general su postura es contraria o se cierra a esta posibilidad (Ayala 2008).

Si bien no se cuenta con discusiones, acuerdos o declaraciones a nivel gremial, se han realizado avances puntuales sobre los reclamos y críticas indígenas en reuniones como la "Jornada de Reflexión sobre patrimonio Arqueológico Indígena en Chile y Propuestas de Gestión" (1996), el "Encuentro de Reflexión sobre Patrimonio Cultural, Comunidades Indígenas y Arqueología" (2001), las diferentes versiones de "Diálogos en la Puna" y el "Simposio Pueblos Originarios y Arqueología" del $51^{\circ}$ Congreso Internacional de Americanistas (2005). Sin embargo, sería optimista decir que se trata de una problemática destacada en la arqueología chilena, ya que estas instancias de discusión han tenido un alcance más bien local o regional. Asimismo, esta temática ha sido escasamente abordada en los congresos nacionales, a excepción del realizado en Valdivia en 2005 donde se efectuó un Foro de Discusión con miembros de las comunidades mapuches.

Por otra parte, el año 2007 la Comisión Nacional de Investigación Científica y Tecnológica (CONICYT) realizó un taller de discusión referido a la bioética en las investigaciones de Ciencias Sociales. En esta ocasión, desde la arqueología se abordó la relación entre los estudios arqueológicos y antropológicos en Rapa Nui y la comunidad (Seelenfreund 2008) y se presentó una reflexión sobre el tratamiento jurídico de los restos óseos indígenas en Chile (González 2008). Ese mismo año, el comité de ética de CONICYT solicitó por primera vez la aprobación de la comunidad indígena a un proyecto de investigación que estudiaría restos óseos del Museo de San Pedro de Atacama. Ante ello el investigador responsable apeló a levantar esta exigencia argumentando que: dicha institución ya autorizó los análisis; estos últimos no causarían daño al material; el proyecto contribuiría a la contextualización de la colección de cráneos del museo y ayudaría a su puesta en valor; y no se trabajaría con individuos vivos de la comunidad ${ }^{10}$. La respuesta del mencionado comité refleja el contexto que se vive en Chile al respecto:

...se suspende el requerimiento de autorización de la comunidad indígena local para el estudio de los restos óseos contemplados en el desarrollo de su investigación, ya que todavía este criterio no se ha instalado en el país... Asimismo, el Comité concuerda en el hecho de considerar que el tema del estudio de restos óseos de comunidades indígenas se encuentra en desarrollo en el país, sin que exista información suficiente sobre las normas éticas a aplicar, así como también ocurre en otras áreas de las Ciencias Sociales" (CONICYT, 04 de Enero de 2008).

\section{Comparando Ambos Casos}

Como se puede observar, en ambos países el retorno a gobiernos democráticos fue el marco político en el cual se generó una normativa favorable al reconocimiento de los derechos de los pueblos indígenas, siguiendo una tendencia común a toda Latinoamérica (Barié 2003). Si bien en la actualidad ambos países ratificaron el Convenio 169 de la OIT, en Argentina esto se llevó a cabo a principios de los años 90 -aunque entró en vigor el 2000-, a diferencia de Chile que lo hizo recién el año 2008. En este contexto, la participación indígena se ha ido afianzando en el caso argentino mientras que en el chileno las repercusiones de su adhesión al Convenio aún se hacen esperar en la legislación indígena y patrimonial vigente.

Las agrupaciones indígenas de ambos países plantearon reclamos y demandas patrimoniales vinculadas con los restos óseos, la entrega de información, el permiso comunitario, la repatriación y el reentierro. Sin embargo, solo Argentina cuenta con una ley que regula estos temas, mientras que Chile ha optado por resolver cuestiones puntuales mediante acuerdos y 
convenios específicos sin sancionar ninguna norma general, a excepción de lo dispuesto sobre la necesidad de consentimiento comunitario para la excavación de cementerios históricos indígenas.

Una coincidencia se registra en la legislación de patrimonio, ya que en ambos casos se ignora la cuestión del patrimonio cultural indígena y, por ende, se abstiene de aplicar los principios generales de reconocimiento, respeto y participación que surgen de la legislación indígena, privando a las comunidades de derechos y garantías de rango constitucional. En el caso argentino se trata de una legislación sancionada el año 2003 y en el chileno de una ley que data de 1970 y que no sufrió modificaciones con la promulgación de la Ley Indígena. El desconocimiento de los derechos patrimoniales de los pueblos indígenas en estos cuerpos legales evidencia un posicionamiento frente a una disputa subyacente sobre el control y la propiedad de los sitios y contextos arqueológicos, que gran parte del mundo académico y científico de ambos países no parece estar dispuesta a ceder. Estas omisiones ponen en evidencia además que en las leyes patrimoniales han tenido una mayor influencia los arqueólogos -ya sea corporativamente a través de sus organizaciones profesionales o de los órganos de aplicación que ellos controlan-, a diferencia de las leyes indígenas que surgen como consecuencia de negociaciones con los representantes de estos pueblos o por iniciativa de otros organismos del Estado vinculados con la problemática étnica. Otra cuestión a considerar es que Argentina, a diferencia de Chile, tiene un sistema federal de gobierno por lo que es necesario que las provincias adhieran a las Leyes Nacionales 25.743 y 25.517 para que sean aplicables en sus jurisdicciones. Pocas provincias han dictado las leyes de adhesión correspondientes, aunque en la práctica las autoridades provinciales suelen fundamentar sus acciones en dichas normas.

Respecto a los estándares éticos, Chile ha sido precursor en la elaboración de principios éticos por parte de la Sociedad Chilena de Arqueología, aunque en ellos se trata de manera muy general y marginal la problemática indígena. En ambos países se han realizado reuniones y encuentros de discusión sobre estos temas, sin embargo, a diferencia del caso argentino que cuenta con un pronunciamiento conjunto de arqueólogos y representantes indígenas de alcance nacional en la Declaración de Río Cuarto, las repercusiones de estas instancias en el caso chileno han sido solo de carácter local o regional. El cariz que ha ido tomando la cuestión de los restos humanos en Argentina quizás explique las diferencias con lo acontecido con Chile. Las recientes iniciativas de la AABA (2007) y la AAPRA (2010) de dictar sus respectivos principios de ética denotan la preocupación por el tema y la necesidad de fijar un posicionamiento al respecto. No obstante lo limitado de su contenido y el tiempo que llevó su aprobación, particularmente en el caso de la AAPRA, demuestra la dificultad para alcanzar consensos entre sus asociados.

Por otra parte, mientras en Argentina el CONICET solicita como recaudo ético que el propio investigador indique si sus investigaciones están alcanzadas por el art. 3 de la Ley 25.517 (es decir, requieren del consentimiento previo de las comunidades indígenas), su homóloga en Chile, CONICYT, plantea que este es un tema que se encuentra en desarrollo y que en el país no existe información suficiente sobre las normas éticas a aplicar para el estudio de restos óseos indígenas.

Respecto de los museos y su actitud frente a los pedidos de restitución y/o no exhibición de restos humanos, no hay una posición homogénea en ninguno de los dos países. En el caso de Argentina el Museo Etnográfico adoptó una política activa de no exhibición y efectúo una restitución voluntaria a Nueva Zelandia sin que mediara pedido alguno. Por el contrario, el Museo de La Plata ha sido el destinatario de la mayoría de los reclamos y durante algunos años fue uno de los principales bastiones de la resistencia -aunque hubo fuertes disensos entre sus investigadores-. Finalmente accedió a retirar los restos humanos de la exhibición en 2004 y recientemente se concretó la restitución de "Damiana" al Paraguay, sin que se contara con una ley especial al respecto. En el caso chileno, después de una historia de conflictos con las comunidades atacameñas, el Museo Arqueológico de San Pedro de Atacama decidió retirar los restos humanos de su exhibición en 2007, lo que no conllevó una apertura al diálogo sobre la devolución y/o reentierro de los mismos. Asimismo, la renovación de la exhibición del museo de la Corporación Cultural y de Turismo de Calama evidencia su posicionamiento activo frente a esta demanda atacameña. Si bien en otros museos del país esta temática ha sido o está siendo discutida entre sus profesionales, hasta la fecha no se cuenta con más ejemplos de instituciones que consideren la no exhibición de restos indígenas dentro de sus políticas. 


\section{Propuesta de Recaudos Éticos en Arqueología}

Sin pretensiones de desarrollar principios que deben ser el fruto de un proceso conjunto de participación, discusión y consenso en la comunidad arqueológica de los países involucrados en este artículo, se señalarán a continuación algunas cuestiones que merecen ser objeto de especiales cuidados por los arqueólogos, en base a lo establecido en la legislación vigente y a los avances logrados en estas materias en estos y otros países.

En primer lugar, la necesidad de contar con el consentimiento previo informado de las comunidades indígenas cuando se quiera investigar en tierras comunales o en sitios que se vinculen a las mismas. Cabe destacar que "consentimiento previo informado" significa que la comunidad contó con toda la información necesaria y suficiente para comprender la naturaleza de los estudios que se pretende realizar y los posibles beneficios o perjuicios que los mismos generan a la comunidad a fin de que esta pueda tomar una decisión. En este sentido, es importante puntualizar que más allá de las modalidades utilizadas para formalizarlo, es necesario considerar que este consentimiento implica un proceso dinámico que debe continuarse mediante el diálogo y la negociación permanente entre las partes (ver Código de Ética de la American Anthropological Association 2009).

En segundo lugar, se debe respetar el derecho de participación de las comunidades, permitiéndoles el acceso al sitio, informándoles sobre los procedimientos de excavación y estudio, proporcionándoles información acerca de los resultados de la investigación de un modo comprensible. Asimismo, se sugiere apoyar e impulsar su participación en los proyectos de investigación, desde el planteamiento del problema de estudio, el trabajo en terreno y laboratorio y la interpretación de la información obtenida.

En tercer lugar, se recomienda identificar posibles conflictos de intereses y trabajar en su prevención a través del diálogo horizontal y la negociación con las comunidades a fin de llegar a decisiones consensuadas.

En relación a los restos humanos, se recomienda tener en cuenta las creencias de los pueblos indígenas al respecto, darles un trato respetuoso durante el proceso de excavación, traslado, estudio, posterior depósito y eventual exhibición ${ }^{11}$. Asimismo, se recomienda tener especial cuidado en hacer constar los restos humanos en los inventarios que se entregan a las autoridades gubernamentales de diferentes jurisdicciones (especialmente en Argentina) durante las etapas del trabajo de campo y de laboratorio.

Finalmente, se sugiere actuar con diligencia y respeto frente a las peticiones efectuadas por comunidades indígenas y dejar constancia de los recaudos éticos observados durante la investigación en las publicaciones resultantes.

\section{Comentarios Finales}

Como señalan Alegría, Gänger y Polanco, existe cierta correspondencia entre la práctica que niega a los indígenas en el presente y el futuro con la negación de su pasado, caracterizada por la arbitrariedad de rechazar su condición de humanos reduciéndolos a meros seres biológicos (Alegría et al. 2009:10).

El reconocimiento de los derechos indígenas en la práctica arqueológica y antropológica presupone en última instancia un quiebre epistemológico. Implica desandar un camino de décadas de exclusividad sobre el "objeto de estudio" y de una actuación profesional destinada a una audiencia selecta, sin tener que rendir cuentas sino a los propios pares. Devolver a los restos depositados en museos o centros de investigación su condición de humanos, implica no sólo unir las partes fragmentadas de los cuerpos y asociarlos a sus archivos, sino también hacer público lo que estaba destinado a ser información reservada a los científicos (Vezub 2009) y renunciar a los "derechos de propiedad" por una simple "tenencia temporaria" de los mismos.

Parecen apropiadas al caso las reflexiones de Orin Starn (1994) acerca del rol de los antropólogos cuando señala que "las disonancias y paradojas de nuestros pasado colonial y nuestro presente poscolonial pueden ser negociadas solo a través de una permanente hermenéutica de reflexión y compromiso (Orin Starn 1994:25-26). En este sentido, señala Verdesio (2010:135) "se necesitan arqueólogos capaces de poner en duda el discurso que afirma que sus investigaciones, que sus manipulaciones de esqueletos humanos, pueden tener un resultado beneficioso para los indígenas".

En los últimos años se ha percibido un cambio de actitud entre los arqueólogos a favor de respetar las creencias ancestrales y de dar participación a las comunidades indígenas, aunque aún son pocos los investigadores que ofrecen abiertamente y de 
motu proprio oportunidades de participación a las comunidades con las cuales interactúan. Sin embargo, no puede desconocerse que los principios reconocidos en la Declaración de Naciones Unidas sobre los Pueblos Indígenas han generado un notable impacto a nivel internacional. Tampoco puede subestimarse su trascendencia en nuestros países, dada la jerarquía que se da a las convenciones sobre derechos humanos en sus respectivas legislaciones y la importancia que la protección de estos derechos tiene en las políticas gubernamentales.

Los arqueólogos debemos ser conscientes que los tiempos y las normativas están cambiando rápida y sustancialmente, y que es imperioso modificar nuestras actitudes y prácticas a fin de evitar incurrir en infracciones legales o conductas antiéticas. En este sentido, puede afirmarse que a nuestra generación le corresponde asumir dos importantes desafíos. El primero consiste en promover un cambio paradigmático en la manera de concebir la tarea profesional, dejando atrás los resabios coloniales que caracterizaron la disciplina y adoptando un rol más activo y significativo en la solución de los problemas de nuestras sociedades en el presente. El segundo, es el de formar a los jóvenes profesionales y estudiantes para actuar en este nuevo escenario político y social, donde el patrimonio cultural es objeto de reclamos y las decisiones respecto del mismo no quedan solo libradas al criterio del profesional actuante.

Agradecimientos: A los evaluadores anónimos por sus valiosos comentarios. Estas investigaciones fueron en parte financiadas por la ANPCyT (PICT 01563/07), MECESUP y CONICYT.

\section{Referencias Citadas}

Alegría, L., S. Gänger y G. Polanco 2009. Momias, cráneos y caníbales. Lo indígena en las políticas de "exhibición" del Estado chileno a fines del siglo XIX. Nuevo Mundo Mundos Nuevos, Debates. Sitio web: http://nuevomundo.revues.org/53063. Consultado el 18/02/ 2011.

Ametrano, S. 2010. Historia de una restitución. Revista Museo 3(21):61-67.

Anyon, R. y R. Thornton 2002. Implementing repatriation in the United States: issues raised and lessons learned. En The Dead and their Possessions: Repatriation in Principle, Policy and Practice, editado por C. Fforde, J. Hubert y P. Turnbull, pp. 190-198. Routledge, Londres.

Ayala, P. 2007. Relaciones entre atacameños, arqueólogos y Estado en Atacama. Estudios Atacameños 33:133-157.

- - - 2008. Políticas del Pasado: Indígenas, Arqueólogos y Estado en Atacama, Línea Editorial IIAM, Santiago.

Aylwin, J. 1989. Tierra mapuche: Derecho consuetudinario y legislación chilena. América Indígena 49(2):369-391.

Barié, C. 2003. Pueblos Indígenas y Derechos Constitucionales en América Latina: Un Panorama. Instituto Indigenista Interamericano, México D.F.

Bray, T. 1996. Repatriation, power relations and the politics of the past. Antiquity 70(268):440-444.

Bolados, P. 2010. Neoliberalismo Multicultural en el Chile Democrático: Gubernamentalizando la Salud Atacameña a través de la Participación y el Etnodesarrollo. Tesis para optar al grado de Doctor en Antropología, Universidad Católica del Norte - Universidad de Tarapacá, San Pedro de Atacama.

Canuhé, G. 2005. Comentario. Declaración de Río Cuarto. Primer Foro Pueblos Originarios-Arqueólogos. Río Cuarto, Argentina, Mayo 2005. Revista de Arqueología Suramericana 1(2):288-289.
Carrasco, M. 2000. Los Derechos de los Pueblos Indígenas en Argentina. Vinciguerra-IWGIA, Buenos Aires.

- - - 2002. El movimiento indígena anterior a la reforma constitucional y su organización en el Programa de Participación de Pueblos Indígenas. LLILAS Publications. The University of Texas, Austin. Sitio web: http://hdl.handle.net/2152/4069. Consultado el 20/02/2011.

CEPIHA 1999. Hallazgos arqueológicos, entre la ciencia y la identidad. Andes 10:245-248.

Deloria Jr., V. 1970. Custer Died for your Sins: An Indian Manifesto. Avon Books, Nueva York.

- - - 1992. Indians, archaeologists, and the future. American Antiquity 57:595-598.

- - - 1995. Red Earth, White Lies: Native Americans and the Myth of Scientific Fact. Scribner, Nueva York.

- - - 1999. Spirit and Reason. The Vine Deloria, Jr. Reader. Fulcrum Publishing, Golden, Colorado.

Echo-Hawk, R. y W. Echo-Hawk 1994. Battlefields and Burial Grounds. The Indian Struggle to Protect Ancestral Graves in the United States. Lerner Publications, Minneapolis.

Endere, M. 2000a. Arqueología y Legislación en Argentina. Cómo Proteger el Patrimonio Arqueológico en Argentina. UNCPBA, Tandil.

- - - 2000b. Patrimonios en disputa: acervos nacionales, investigación arqueológica y reclamos étnicos sobre restos humanos. Trabajos de Prehistoria 57(1)2000:1-13.

- - - 2002. The reburial issue in Argentina: A growing conflict. En The Dead and their Possessions: Repatriation in Principle, Policy and Practice, editado por C. Fforde, J. Hubert y P. Turnbull, pp 266-283. Routledge, Londres. 
- - - 2005. Talking about others: Archaeologists, indigenous peoples and heritage in Argentina. Public Archaeology 4:155-162.

- - - 2007. Management of Archaeological Sites and the Public in Argentina. BAR International Series 1708. Archaeopress, Oxford.

Endere, M. y R. Curtoni 2006. "Entre Lonkos y "ólogos": la participación de la comunidad ranquelina en la investigación arqueológica”. Revista de Arqueología Suramericana 2:72-92.

Escolar, D. 2007. Los Dones Étnicos de la Nación. Identidades Huarpe y Modos de Producción de Soberanía en Argentina. Prometeo, Buenos Aires.

González, J.A. 2005. Los pueblos originarios en el marco de sus derechos. Estudios Atacameños 30:79-90.

González, P. 2001. Régimen Jurídico de Protección del Patrimonio Cultural y de los Pueblos Indígenas en la Legislación Chilena. Memoria para optar al grado de Licenciado en Ciencias Jurídicas y Sociales, Departamento de Derecho Privado, Facultad de Derecho, Universidad de Chile, Santiago.

- - - 2008. Tratamiento jurídico de los restos óseos indígenas en Chile: su implicancia para la investigación científica. En Bioética en Investigación en Ciencias Sociales, $3^{\circ}$ Taller Organizado por el Comité Asesor de Bioética de FONDECYT-CONICYT, Santiago, 141-172.

Hubert, J. 1992. Dry bones or living ancestors? Conflictive perceptions of life, death and the universe. International Journal of Cultural Property 1:105-127.

Hurst, T. 2000. Skull Wars: Kennewick Man, Archaeology and the Battle for Native American Identity. Basic Book, Nueva York.

Jofré, I., S. Biasatti y G. González 2010. Los fantasmas capitalistas de una arqueología de los muertos. En El Regreso de los Muertos y las Promesas del Oro. Patrimonio Arqueológico En Conflicto, coordinado por I.C. Jofré, pp. 169-194. Encuentro Grupo Editor, Editorial Brujas, Córdoba.

Kroeber, T. 1961. Ishi in Two Worlds. A Biography of the Last Wild Indian in North America. University of California Press, Berkeley.

Lazzari, A. 2003. Aboriginal recognition, freedom, and phantoms: The vanishing of the Ranquel and the return of the Rankülche in La Pampa. The Journal of Latin American Anthropology 8(3):59-83.

- - - 2010. The Autonomy of the Appeared: Phantom Indian, Selves, and Freedom (on the Rankülche in Argentina). Tesis doctoral inédita. Graduate School of Arts and Sciences. Universidad de Columbia.

Morell, V. 1995. Who owns the past? Science 268:1424-1426.

Paillalef, J. 2010. El mensaje de los Kuviche en el Llew-Llew. En Arqueología y Pueblos Indígenas en América Latina, editado por C. Gnecco y P. Ayala, pp. 479-485. Universidad de los Andes y Banco de la República, Bogotá.

Pavez Ojeda, J. (comp.) 2008. Cartas Mapuche: Siglo XIX. CoLibris-Ocho Libros, Santiago.

Pepe, F., M. Suárez y P. Harrison 2008. Antropología del Genocidio. Identificación y Restitución: "Colecciones" de Restos Humanos en el Museo de La Plata. Colectivo GUIAS, edición del autor, La Plata.
Pérez Gollán, J. 2005. Comentario. Declaración de Río Cuarto. 2005. Primer Foro Pueblos Originarios - Arqueólogos. Río Cuarto, Argentina, Mayo 2005. Revista de Arqueología Suramericana 1(2):290-203.

Podgorny, I. y G. Politis 1992. ¿Qué sucedió en la historia? Los esqueletos araucanos del Museo de La Plata y la Conquista del Desierto. Arqueología Contemporánea 3:73-79.

Politis, G. 2001. On archaeological praxis, gender bias and indigenous peoples in South American. Journal of Social Archaeology 1:90-107.

Quijada, M. 1998. Ancestros, ciudadanos, piezas de museo. Francisco P. Moreno y la articulación del indígena en la construcción nacional argentina (siglo XIX). Estudios Interdisciplinarios de América Latina y el Caribe 9(2):21-46.

Rockafellar, N. y O. Starn 1999. Ishi's brain. Current Anthropology 40:413-416.

Seelenfreund, A. 2008. La investigación antropológica y arqueológica en Rapa Nui y su relación con la comunidad. En Bioética en Investigación en Ciencias Sociales, $3^{\circ}$ Taller Organizado por el Comité Asesor de Bioética de FONDECYT-CONICYT, Santiago, pp. 97-114.

Sepúlveda, T. y P. Ayala 2008. La exhibición de cuerpos humanos en los museos: una reflexión a partir del caso de San Pedro de Atacama. Revista Museos 27:49-53.

Sepúlveda, T., P. Ayala y C. Aguilar 2008. Retiro de los cuerpos humanos de la exhibición del Museo Arqueológico de San Pedro de Atacama. IX Seminario sobre Patrimonio Cultural "Museos en Obra”, DIBAM, Santiago, pp. 114-132.

Slavsky, L. 1992. Los indígenas y la sociedad nacional. Apuntes sobre políticas indigenistas en la Argentina. En La Problemática Indígena. Estudios Antropológicos sobre Pueblos Indígenas in Argentina, editado por A. Balazote y J.C. Radovich, pp 67-79. Centro Editor de América Latina, Buenos Aires.

- - - 1997. Transformaciones en el discurso legislativo argentino sobre el indígena (1930-1955). Trabajo presentado en el $V$ Congreso de Antropología Social La Plata, 29 de julio al 1 de agosto de 1997. Sitio web:http://www.naya.org.ar/congresos/ contenido/laplata/LP5/8.htm. Consultado el 17/03/2011.

Starn O. 1994. Rethinking the politics of anthropology: The Case of the Andes. Current Anthropology 35:13-38.

Swidler, N., K. Dongoske, R. Anyon y A. Downer (eds.) 1997. Native American and Archaeologists. Stepping to common ground. Altamira Press, Londres.

Verdesio, G. 2010. El drama de la restitución de restos humanos y sus actores en Uruguay y Argentina: El Estado, los/las Arqueólogos/as y las Comunidades de Pueblos Originarios. En El Regreso de los Muertos y las Promesas del Oro. Patrimonio Arqueológico en Conflicto, coordinado por I.C. Jofré, pp. 123140. Encuentro Grupo Editor, Editorial Brujas, Córdoba.

Vezub, J. 2009. Henry de La Vaulx en Patagonia (1896-1897): la historicidad escindida de la antropología colonial y la captura de corpus y cuerpos. Nuevo Mundo Mundos Nuevos. Debates. Sitio web: http://nuevomundo.revues.org/57810. Consultado el 18 febrero 2011. 
Webb, S. 1987. Reburying Australian skeletons. Antiquity 61:292-6.

Zimmerman, L. 1987. Webb on reburial: A North American perspective. Antiquity 61:462-463.
- - - 1989. Made radical by my own: An archaeologist learns to accept reburial. En Conflict in the Archaeology of the Living Traditions, editado por R. Layton, pp. 60-67. Routledge, Londres.

\section{Notas}

1 Diversas organizaciones que defendían los derechos civiles de los pueblos indígenas trabajaron de manera conjunta en pos de la repatriación de los restos humanos indígenas dando origen al denominado "reburial issue" (e.g. American Indians Against Desecration, National Congress of American Indians y Native American Rights Fund).

2 Han sido de significativa importancia también la Declaración Conjunta sobre Repatriación de Restos Humanos firmada por los Primeros Ministros de Reino Unido y Australia en 2003 y la ley de Reino Unido conocida como Human Tissue Act 2004.

3 Argentina adhirió al Código de Deontología de ICOM mediante Resolución 1011/05 de la Secretaría de Cultura de la Presidencia de la Nación.

4 El art. 2 de la Ley 23.302 establece que "se entenderá como comunidades indígenas a los conjuntos de familias que se reconozcan como tales por el hecho de descender de poblaciones que habitaban el territorio nacional en la época de la conquista o colonización e indígenas o indios a los miembros de dicha comunidad".

5 En el 2010 se creó en Tucumán el Colegio de Profesionales en Arqueología de dicha provincia (Ley 8.337).

6 Este hallazgo fue objeto de reclamos de diferentes agrupaciones indígenas. Cuando se hizo público el espectacular hallazgo de las tres momias incaicas en el santuario de altura, la Asociación Kolla Los Airampos denunció penalmente la violación de los derechos de la comunidad por tratarse de un sitio sagrado ancestral (Causa 523/99 Juzgado Federal, Primera Instancia Penal 2, Salta). Posteriormente diferentes agrupaciones indígenas se opusieron a su exhibición en el Museo creado a tal fin de la ciudad de Salta (Endere 2005; Politis 2001). Si bien ninguno de los dos reclamos fue exitoso, el debate que este caso originó entre los investigadores motivó la realización de importantes reuniones y la adopción de recomendaciones. En 2005 se produjo un entredicho entre las autoridades del Museo de Salta y la Dirección de Patrimonio y Museos de la Nación que abogaba por la aplicación de los principios del Código Deontológico del ICOM.

7 Un caso que presenta similitudes sorprendentes con el caso de Inakayal es el de Ishi, no sólo porque ambos vivieron en los museos antes de pasar a formar parte de sus colecciones, sino por las vicisitudes de su restitución. Inakayal vivió sus últimos años en el Museo de La Plata gracias a gestiones de su director Francisco P. Moreno, quien lo sacó de la cárcel donde había sido injustamente enviado (Endere 2002; Podgorny y Politis 1992;). Ishi, considerado el último Yahi, encontrado en 1911, vivió en el Museo de Antropología de la Universidad de California bajo la protección de Alfred Kroeber hasta su muerte (Kroeber 1961). Si bien las cenizas de Ishi fueron llevadas al Cementerio de Olivert en San Francisco nunca se supo el destino de su cerebro por lo que el Butte County Native American Cultural Committee lanzó una campaña en 1997 para reclamar su repatriación para enterrar los restos completos de Ishi en tierras ancestrales. Luego de una ardua investigación en la que participaron antropólogos se pudo determinar que el cerebro, se encontraba en el NMNH del Smithsonian que efectuó finalmente su devolución (Rockafellar y Starn 1999).

8 Durante el siglo XIX en Chile, al igual que en la Argentina, se acumularon, clasificaron y exhibieron restos humanos (Pavez Ojeda 2008) en museos e instituciones patrimoniales que albergan hoy una cantidad de cráneos procedentes de Chile y Perú, así como esqueletos y momias (Alegría et al. 2009).

9 Cabe mencionar que a finales del 2009 se constituyó el Colegio de Arqueólogos de Chile, siendo uno de sus objetivos el de redactar un código de ética.

10 Carta enviada por M. Hubbe, responsable del Proyecto FONDECYT 11070091.

11 Ver Guidance for the care of Human Remains in Museum, publicadas por el Department of Culture, Media and Sport de Reino Unido en 2005. Sitio web: http://www.culture. gov.uk/reference_library/publications/3720.aspx. 
